\title{
MHC Class I Polypeptide-Related Sequence $A$
}

National Cancer Institute

\section{Source}

National Cancer Institute. MHC Class I Polypeptide-Related Sequence A. NCI Thesaurus.

Code C126961.

MHC class I polypeptide-related sequence $\mathrm{A}(383 \mathrm{aa}, \sim 43 \mathrm{kDa}$ ) is encoded by the human MICA gene. This protein plays a role in the negative regulation of natural killer cells. 